\title{
Impact of Population Growth, Poverty and Unemployment on Economic Growth
}

\section{Umar Bala ${ }^{1 \star \text { (iD }}$ \\ Aminu Ibrahim² Nazeef Bala Hadith ${ }^{3}$}

\author{
${ }^{1,2}$ Department of Economics, Faculty of Social and Management Sciences Bauchi State University, Gadau Nigeria. \\ 'Email.ubul1@yahoo.co.uk.Tel.+23480327s9714 \\ 'Email:ameenuib@gmail.com Tel.+2s48037047097 \\ ${ }^{4}$ National University Commission (NUC) Garki GPO, Maitama Abuja, Nigeria. \\ ${ }^{s}$ Email:nazeefysk@yahoo.co.ukTel.+234803s671498
}

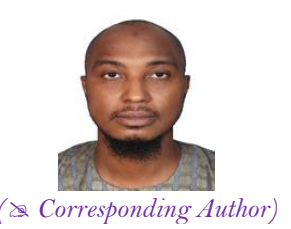

(T) Check for updates

\begin{abstract}
This research explores the impact of population growth, poverty and unemployment on economic growth in Nigeria using Auto Regressive Distributed Lag (ARDL). The study employed an econometric procedure; unit root test which involved the use of Augmented Dickey Fuller test (ADF) and Phillip-Perron test (PP). The cointegration test technique used in the study is Auto Regressive and Distributed Lag (ARDL). The study variables are real GDP, population, poverty, unemployment and foreign direct investment has control variable. The null hypothesis stated that there is presence of a unit root was failed to be rejected at levels but rejected at first difference according to the two tests (ADP and PP) employed. The study found that some of the variables are stationary at level $\mathrm{I}(\mathrm{O})$ while others are stationary at first difference $\mathrm{I}(1)$. The results of the cointegration test showed that there exist cointegrating equation between explanatory variables and economic growth. The ECT speed of adjustment to the normal equilibrium confirms their long run relationship of the variables. Finally, the study found that population and FDI have a positive impact while poverty and unemployment has negative impact on GDP. Based on these findings recommend that policy makers should grow the real economic sectors to improve and enhance productivity, exports, job creation, curb inflation and reduce poverty and rapid economic growth and substitute the non-productive imports with domestic products and develop enabling environment to attract foreign private investors.
\end{abstract}

Keywords: Population growth, Poverty, Unemployment, Economic growth, foreign direct investment, ARDL bound test. JEL Classification: I39.

\section{Introduction}

There are so many problems recently in problem in Nigeria which associated with high population grow especially in urban areas. Increases in growing population causes high level of unemployment in the urban area and translate to poverty. Moreover, the presence of increases numbers of poorer and jobless individuals in the society generates insecurity (Frank, 2010). In most of the populated area has deficiency to acquire basic human need and social amenities. Most of the people are farmers which categories as seasonal unemployment. When the level of unemployed people are high without corresponding human basic need the rate of crime increases. In Nigeria there is still high rate of unemployment with translate to poverty and infrastructural deficit (Okolobah \& Ismail, 2013). Several decades ago in Nigeria, agriculture seemed to be the major source of livelihood and as a result population growth was positively linked to production. It was believed that more people imply greater productivity and security since more workers or laborers working efficiently would be expected to immensely improve productivity and the overall output of the nation (Tartiyus, Dauda, \& Peter, 2015). When the societies and economies began to flourish, success was dependent upon a productive agricultural sector and attributed to large population. The economy inevitably expanded and the society reaped the financial benefits with more efficient labor. The high fertility rates allowed for increased laborers, enhanced productivity, facilitated economic activities and helped overcome the previously recorded exorbitant death rates as a result of combined effects of famine, disease, malnutrition, plague and war (Latimer \& Kulkarni, 2008). The level of unemployment and poverty have continue to be core obstacle confronting the Nigerian economy (Adelowokan, Maku, Babasanya, \& Adesoye, 2019).

According to world bank development indicators Nigeria has a population of about 200,963,599 million people in 2019 and a land area of $923,768 \mathrm{~km}^{2}$, Nigerian economy is the largest economy in African region (OPEC, 2015). The measurement of size and growth of the economy Nigeria is re-basing its GDP data from 1990 to 2008 . A preliminary forecast of the rebasing is about a 40 percent increase in the total GDP; i.e. from a 2012 IMF estimate of USD 270 billion to USD 375 billion. This would bring Nigeria's GDP behind South Africa's GDP of USD 390 billion, making Nigeria the 30th largest economy in the world from the previous 40th position. The structure of the Nigerian economy is predominantly primarily product oriented (agriculture and crude-oil production). The projected growth rate of 6.75 percent appears conservative given the potential for double digit growth. Also there necessity to achieve 
higher growth rates in order to actualize it goal to become one of the top 20 economies in the world by the year 2020. The planned rebasing of the Gross Domestic Product (GDP) is anticipated to boost the size of the economy possibly to become the largest in Africa. But it will lead to a reduction in future GDP growth. Irrespective of the potential increase in the size of the Nigerian economy, Nigeria is still facing some setback in economic sector such as militants, inflation, unemployment, poverty, insecurity problem and corruption.

The 2020 budget shows that the federal government will remain focusing on major actions to control the disorder in the Country particularly in Northern part and to consolidate on the relative peace in the Niger-Delta post-amnesty. In 2020, the effect of Covid 19 turn the real GDP grow into negative accomplish by the declining global crude oil price and production cut challenges in an economy that is the still predominantly oil based. The alternative way to compensate the deficit growth from the oil sector is by creating alternative sources that will drive the economy forward. To achieve this, government must pay attention on fiscal and monetary policies that will drive the non-oil sectors of the economy. The sectors driving the economic growth were not sufficiently high job creating sectors. Furthermore, the oil industry is a capital-intensive virtual enclave that generates very little employment and the rate of poverty still increases among the citizens. Figure 1 we can see that population, unemployment and poverty are still increasing which may affect economic growth. It can be observed that all the trends of the variable are increases especially the unemployment rate from 2015 to 2019 which has direct corresponding effect on poverty rate has shown in the chart.


\section{Literature Review}

The relationship between population growth, unemployment and poverty on economic growth, is a very common debate in the economic literature. Numerous empirical and theoretical studies have been carried out on the areas. Mamingi and Perch (2013) examined the effect of population growth on economic growth/development in Barbados for the period 1980-2010. Using the Autoregressive distributed lag approach to cointegration, the study revealed that population growth and population density positively and significantly affects economic growth, economic growth negatively and significantly affects population growth, natural increase rate positively and significantly affects population growth, also that net international migration negatively and significantly impacts population growth. The study failed to give any recommendations. The results from this study have policy implications on the grounds that, with increases in population comes a larger market and these are transformed into growing consumption accompanied by rise in investment which is the needed prerequisite for economic growth.

Njoku and Ihugba (2011) found that agriculture activities have the major contribution and the main source of employment in the Nigeria contributed more than the oil sector. Ukpong, Ekpebu, and Ofem (2013) study about poverty and population growth in Nigeria found that there is positive relationship between poverty rate and population growth, and negative relationship between GDP real growth rate and poverty rate in Nigeria while Maijamaa, Saidu, Muktari, and Nafisa (2019) studies the relationship between population growth and unemployment found that that population positively increase unemployment whereas foreign direct investment reducing the rate of unemployment in the long-run. Kurnianto, Rakhmasari, Ikhsan, Apriyanto, and Nurdin (2018) used secondary data source found that population growth, economic growth and unemployment, have significant impact on the poverty level in Indonesia. Mamingi and Perch (2013) study Barbados population growth found that population density have positive and significantly effect on economic growth. Tartiyus et al. (2015) used regression analysis the result reveals that there is a positive relationship between population and economic growth.

Aiyedogbon (2012) used time series data found that unemployment, agricultural and services contributions to real GDP as well as population is the responsible increase the level of poverty in Nigeria. Osinubi (2005) argue that economic growth has not grantee to reduce the level of poverty and unemployment. Chisom and Oluchukwu (2017) study the relationship between poverty and unemployment found that poverty and unemployment have positive and significant correlation in Nigeria. Odeh and Okoye (2014) studies that poverty reduction policies in relation to youth unemployment found that that majority of the youth portion of the Nigerians lives below the poverty line, due to unemployment rate. Nwosa (2014) apply an Ordinary Least square (OLS) estimation technique found that 
government expenditure has positive and significant impact on unemployment rate while it has a negative and insignificant impact on poverty rate. Adewale and Ademola (2017) apply causality test found is two ways causality between unemployment rate and poverty in Nigeria. Also in Pakistan Meo et al. (2018) apply ARDL bound test found that there is asymmetries relationship between inflation, unemployment and poverty. Bala, Ayatu, and Maijamaa (2020) and Mansoor (2018) found that population growth has direct impact on energy generation and demand in Nigeria and Pakistan.

\section{Methodology}

This paper builds on Okun's model by adding population and poverty to find their effect on economic growth of Nigeria. The study used annual time series data between 1980 and 2017. In addition, Eviews9 was used as statistical software for analyzing the available data, which has been transformed to their natural logarithm. All the data are sourced from World Development Indicators of World Bank (WDI).

\subsection{Unit Root Test}

Unit root test: in order to determine the level of stationarity of the variable unit root test has to be conducted which most usual and accepted test by (Augmented Dickey Fuller (ADF) and Philips Perron (PP). If the null hypothesis was not rejected of non-stationary at level, then the study will further test the variables in the first difference.

Assume $X$ to be any variable and the Augmented Dickey-Fuller (ADF) model can be defined as follows:

$$
\Delta X_{t}=\beta_{1}+\beta_{2} t+\delta X_{t-1}+\sum_{i=1}^{m} \alpha_{i} \Delta X_{t-i}+\varepsilon_{t}
$$

Where $\varepsilon_{t}$ is a pure white noise error term and $\Delta X_{t-1}=\left(X_{t-1}-X_{t-2}\right), \quad \Delta X_{t-2}=\left(X_{t-2}-X_{t-3}\right)$, $\Delta X_{t-i}=\left(X_{t-i}-X_{t-j}\right)$, and $i$ represents the number of recent time and $j$ as the number of previous times or years. The hypothesis of Augmented Dickey Fuller ADF is

$$
\begin{gathered}
H_{0}: \delta=0, X_{t} \text { is non-stationary, (unit root) } \\
H_{0}: \delta \neq 0, X_{t} \text { is stationary, (no unit root) }
\end{gathered}
$$

The first differencing in unit root test is to be tested if non-stationary time series $Y$ need to be "differenced" at the times to make it stationary. Then the result can be stationary and correct, hence one can proceed to test for the co-integration.

\subsection{Autoregressive and Distributed Lag Co-Integration Bound Test}

After the test for the order of integration, the next step is to test for co-integration. This test is used to check if long run relationship exists among the variables in the model. This will be carried out using the ARDL Bound technique.

\subsection{Decision Rule}

Ho: $\alpha_{1}=\alpha_{2}=\alpha_{s}=\alpha_{t}=\alpha_{s}=O$ (there is no co-integration among the variables)

$H_{1}: \alpha_{1} \neq \alpha_{2} \neq \alpha_{3} \neq \alpha_{*} \neq \alpha_{5} \neq O$ (there is co-integration among the variables)

If the $\mathrm{F}$ statistics is below the $\mathrm{I}(0)$ we cannot reject Ho but if the $\mathrm{F}$ statistics is higher than the $\mathrm{I}(1)$ bound, then we reject $\mathrm{Ho}$ and accept the $\mathrm{H}_{1}$. This means that there is co-integration among the variables of study.

The generalized ARDL (p, q) model is specified as:

$$
Y_{t}=\gamma_{0 i}+\Sigma_{i}=1 p \delta_{i} Y_{t}=I+\Sigma_{q i}=0 \beta_{i} X_{t}=I+\mu_{i t}
$$

Where $\mathbf{Y}$ is a vector and the variables in $(\mathbf{X})$ are allowed to be purely I (0) or I (1) or cointegrated; $\beta$ and $\delta$ are coefficients; $\gamma$ is the constant; $i=1$, p, q are optimal lag orders; $\mu$ is a vector of error terms unobservable zero mean while noise vector process (serially uncorrelated or independent).

\subsection{Model Specification}

From Okun's model we develop a simple equation to capture the objective of this paper;

$$
G D P_{t}=f\left(P O P_{t}, P O V_{t}, U N E M_{t}, F D I_{t}\right)
$$

Transforming the function in to econometric model, we have the following:

If we transform it in to a $\log$ form, we have;

$$
G D P_{t}=\beta_{0}+\beta_{1} P O P_{t}+\beta_{2} P O V_{t}+\beta_{3} U N E M_{t}+\beta_{4} F D I_{t}+\varepsilon_{t}
$$

$$
\ln G D P_{t}=\beta_{0}+\beta_{1} \ln P O P_{t}+\beta_{2} \ln P O V_{t}+\beta_{3} \ln U N E M_{t}+\beta_{4} \ln F D I_{t}+\varepsilon_{t}
$$

Where, $G D P_{t}$ is gross domestic product, which is the dependent variable $\beta_{0}$ is expected to be positive. $\beta_{0}>1$

$P O P_{t}$ is population growth with the rate at which the Nigerian population growing. Thus, its coefficient $\beta 1$, is expected to be positive on economic growth i.e., $\beta 1>0$.

$P O V_{t}$ is poverty which is not having enough material possessions or income for a person's needs. Therefore, the coefficient is expected to be negative $(\beta 2<0)$.

$U N E M_{t}$ is unemployment, this is number of people that have no job to do in Nigeria. Thus, its coefficient $\beta 3$, is expected to be negative i.e., $\beta 3<0$.

$F D I_{t}$ is foreign direct investment it is an investment in the form of a controlling ownership in a business in one country by an entity based in another country. Thus, its coefficient $\beta 4$, is expected to be positive i.e., $\beta 4>0$

The unrestricted error correction model, (ECM) for ARDL is specified below: 


$$
\begin{aligned}
& \Delta \operatorname{lnGDP_{t}}=\beta_{1 t}+\sum_{\mathrm{i}=1} \alpha_{1 i} \Delta \ln G D P_{t-i}+\sum_{\mathrm{i}=0} \beta_{1 i} \Delta \ln P O P_{t-i}+\sum_{\mathrm{i}=0} \delta_{1 i} \Delta \ln P O V_{t-i}+\sum_{\mathrm{i}=0} \chi_{1 i} \Delta \ln U N E M_{t-i} \\
& +\sum_{i=0}^{i=1} \partial_{1 i} \Delta \ln F D I_{t-i}+\theta_{1} \ln G D P_{t-1}+\theta_{2} \ln P O P_{t-I}+\theta_{4} \ln P O V_{t-1}+\theta_{3} \ln U N E M_{t-I} \\
& +\theta_{5} \ln \ln F D I_{t-I}+\varepsilon_{t}
\end{aligned}
$$

Where $\Delta$ is first difference operator and $k$ is optimal lag length.

Long-run equation

Short-run equation

$$
\begin{aligned}
\ln G D P_{t}=\beta_{2 t} & +\sum_{\mathrm{i}=1} \alpha_{2 i} \ln G D P_{t-i}+\sum_{\mathrm{i}=0} \beta_{2 i} \ln P O P_{t-i}+\sum_{\mathrm{i}=0} \delta_{2 i} \ln P O V_{t-i}+\sum_{\mathrm{i}=0} \chi_{2 i} \ln U N E M_{t-i} \\
& +\sum_{\mathrm{i}=0} \partial_{2 i} \ln F D I_{t-i}+\varepsilon_{2 t}
\end{aligned}
$$

$$
\begin{aligned}
\Delta \operatorname{lnGDP} P_{t}=\beta_{3 t} & +\sum_{\mathrm{i}=1} \alpha_{3 i} \Delta \operatorname{lnGDP_{t-i}}+\sum_{\mathrm{i}=0} \beta_{3 i} \Delta \ln P O P_{t-i}+\sum_{\mathrm{i}=0} \delta_{3 i} \Delta \ln P O V_{t-i}+\sum_{\mathrm{i}=0} \chi_{3 i} \Delta \ln U N E M_{t-i} \\
& +\sum_{\mathrm{i}=0} \partial_{3 i} \Delta \ln F D I_{t-i}+\lambda E C T_{t-1}
\end{aligned}
$$

Error correction term (ECT) in equation

$$
\begin{aligned}
E C T_{t}=\ln G D P_{t} & -\beta_{2 t}-\sum_{i=1} \alpha_{2 i} \operatorname{lnGDP_{t-i}}-\sum_{\mathrm{i}=0} \beta_{2 i} \ln P O P_{t-i}-\sum_{\mathrm{i}=0} \delta_{2 i} \ln P O V_{t-i}-\sum_{\mathrm{i}=0} \chi_{2 i} \ln U N E M_{t-i} \\
& -\sum_{\mathrm{i}=0} \partial_{2 i} \ln F D I_{t-i}
\end{aligned}
$$

Where $\lambda$ is the coefficient of the error correction term which measures the speed of adjustment of the variables toward convergence to equilibrium In addition, the coefficient provides information about the long-run relationship among the variables. To complete the estimation process, diagnostic tests will be conducted to assess the reliability and efficiency of the estimates.

\section{Results and Discussions}

The major concern of this part is to presents analytical discussions on the results effort was made to establish a results and at the same time justify the authenticity of the statement analysis and interpretations of the data. Table 1 shows the conducted Augmented Dickey-Fuller (ADF) test and the Phillips-Perron (PP) test results for more

\begin{tabular}{|c|c|c|c|c|c|c|c|c|}
\hline & \multicolumn{4}{|c|}{ ADF Test Statistics } & \multicolumn{4}{|c|}{ PP Test Statistics } \\
\hline & \multicolumn{2}{|c|}{ Constant } & \multicolumn{2}{|c|}{ Trend } & \multicolumn{2}{|c|}{ Constant } & \multicolumn{2}{|c|}{ Trend } \\
\hline & Level & $\begin{array}{c}\text { First } \\
\text { Difference }\end{array}$ & Level & $\begin{array}{c}\text { First } \\
\text { Difference }\end{array}$ & Level & $\begin{array}{c}\text { First } \\
\text { Difference }\end{array}$ & Level & $\begin{array}{c}\text { First } \\
\text { Difference }\end{array}$ \\
\hline $\ln G D P_{t}$ & $\begin{array}{l}-0.783 \\
(0.811) \\
\end{array}$ & $\begin{array}{c}-4.121 \\
(0.002)^{* * *} * \\
\end{array}$ & $\begin{array}{l}-2.223 \\
(0.462) \\
\end{array}$ & $\begin{array}{c}-3.317 \\
(0.080)^{*}\end{array}$ & $\begin{array}{c}0.866 \\
(0.993) \\
\end{array}$ & $\begin{array}{c}-4.159 \\
(0.002)^{* * *} * \\
\end{array}$ & $\begin{array}{c}-3.946 \\
(0.019) * * \\
\end{array}$ & $\begin{array}{c}-3.843 \\
(0.025)^{* *}\end{array}$ \\
\hline $\ln \mathrm{POP}_{t}$ & $\begin{array}{c}-6.102 \\
(0.000)^{* * * *} \\
\end{array}$ & $\begin{array}{c}-3.565 \\
(0.013)^{* * *} \\
\end{array}$ & $\begin{array}{c}-6.119 \\
(0.000)^{* * *} * \\
\end{array}$ & $\begin{array}{l}-1.731 \\
(0.710) \\
\end{array}$ & $\begin{array}{c}-3.417 \\
(0.016)^{* *} \\
\end{array}$ & $\begin{array}{c}-4.046 \\
(0.003)^{* * *} * \\
\end{array}$ & $\begin{array}{c}-3.931 \\
(0.020)^{* *} \\
\end{array}$ & $\begin{array}{c}-3.445 \\
(0.061)^{*}\end{array}$ \\
\hline $\ln \mathrm{POV}_{t}$ & $\begin{array}{c}0.573 \\
(0.986)\end{array}$ & $\begin{array}{c}3.202 \\
(1.000)\end{array}$ & $\begin{array}{c}4.079 \\
(1.000)\end{array}$ & $\begin{array}{c}2.421 \\
(1.000)\end{array}$ & $\begin{array}{c}5.816 \\
(1.000)\end{array}$ & $\begin{array}{l}-1.825 \\
(0.362)\end{array}$ & $\begin{array}{c}3.381 \\
(1.000)\end{array}$ & $\begin{array}{c}-4.869 \\
(0.002)^{* * *}\end{array}$ \\
\hline $\ln U N E M t$ & $\begin{array}{c}-3.786 \\
(0.006)^{* * *}\end{array}$ & $\begin{array}{c}-5.692 \\
(0.000)^{* * *} *\end{array}$ & $\begin{array}{c}-4.138 \\
(0.012)^{* *}\end{array}$ & $\begin{array}{c}-5.672 \\
(0.000)^{* * *} *\end{array}$ & $\begin{array}{l}-2.020 \\
(0.277) \\
\end{array}$ & $\begin{array}{c}-6.370 \\
(0.000)^{* * *} *\end{array}$ & $\begin{array}{l}-2.140 \\
(0.507)\end{array}$ & $\begin{array}{c}-6.903 \\
(0.000)^{* * * *}\end{array}$ \\
\hline $\ln F D I_{t}$ & $\begin{array}{l}-1.620 \\
(0.462)\end{array}$ & $\begin{array}{c}-11.383 \\
(0.000)^{* * *} *\end{array}$ & $\begin{array}{c}-5.474 \\
(0.000)^{*} * *\end{array}$ & $\begin{array}{c}-11.245 \\
(0.000)^{* * *} *\end{array}$ & $\begin{array}{l}-1.396 \\
(0.573)\end{array}$ & $\begin{array}{c}-11.169 \\
(0.000)^{* * *} *\end{array}$ & $\begin{array}{c}-3.772 \\
(0.029)^{*} * \\
\end{array}$ & $\begin{array}{c}-11.245 \\
(0.000)^{* * *} *\end{array}$ \\
\hline
\end{tabular}
reliability and stationarity of the data. The T-statistic and the p-value of each of the tests must be observed. If the pvalue is less than (0.05) reject the null hypothesis of non-stationarity and accept the alternative hypothesis of stationarity, otherwise accept the null hypothesis of non-stationarity. The results of the tests revealed that GDP, poverty and Foreign Direct Investment are stationary after first difference that is I(1), while population and unemployment are stationary at level that is $\mathrm{I}(0)$. This indicate a mixture of order of integration that is $\mathrm{I}(0)$ and $\mathrm{I}(1)$. As such ARDL methodology is the most fitted methodology to apply.

Table-1. Unit root test.

\subsection{Cointegration Tests}

After determining the stationarity of the data, the next step is to estimate the long relationship among the variables. But before then, we have to determine the optimal lag to be used. Prior to carrying out the task, an optimum lag length for the model was selected based on Akaike Information Criterion (AIC) which suggested Lag 4 for the model. The cointegration result presented in Table 2 shows that the model has cointegration as the calculated F statistics (9.261731) based on the optimum lags selected exceed the upper bound of the critical values table developed by Narayan and Narayan at $5 \%$. This result indicates that the variables in the model have a long-run equilibrating relationship. As such, we could go on and estimate the long-run model of the ARDL specification. 
Table-2. ARDL bound test results.

\begin{tabular}{l|c|c|c|c|c|c}
\hline \multicolumn{1}{c|}{ Model } & F - Statistics & Lag & $\begin{array}{c}\text { Level Of } \\
\text { Significance }\end{array}$ & \multicolumn{2}{c}{$\begin{array}{c}\text { Bound Test Critical Values } \\
\text { (Constant Level) }\end{array}$} \\
\hline$G D P$ & & & & \multicolumn{2}{|c}{$\mathbf{I}(\mathbf{0})$} & \multicolumn{2}{|}{$\mathbf{I}(\mathbf{1})$} \\
\hline$(P O P, P O V, U N E M P, F D I)$ & 9.2617 & 4 & $10 \%$ & 2.45 & 3.52 \\
\hline & & & $5 \%$ & 2.86 & 4.01 \\
\hline & & & $2.5 \%$ & 3.25 & 4.49 \\
\hline
\end{tabular}

Note: Based on Narayan Table Case III (Narayan, 2005).

\subsection{Long-Run and Short-Run Results}

Table 3 below presents the results of the long-run and short-run equations for the Model. The presence of longrun equilibrium relationship among the variables as found from the ARDL bound test led to the application of ARDL. With this approach, both the long-run equilibrium and short-run dynamic relationships associated with the variables under the study are established. In the long run, population has a positive impact on GDP. A unit change in population will result in increase in GDP by 5.956. Population is remain the main factor of human capital accomplish which education, health and productivity. Poverty on the other hand has a negative impact on GDP and the relationship is statistically significance. Precisely 1 per cent increases in poverty will cause GDP to decrease by 6.652. The level of poverty in Nigeria is high accomplished which inequality and corruption.

Similarly, Unemployment has a negative and significant impact on GDP, 1 per cent increases in unemployment will result GDP to decrease by -0.312. This result sounds counterintuitive because unemployment leads to lower productivity, malnutrition, and high cost of living. Foreign Direct Investment has a negative and statistically significant impact on GDP. That is, 1per cent increases in Foreign Direct Investment will result in increase in GDP by 0.138 . The FDI result similarly sounds counter intuitive like unemployment as FDI leads to more job opportunities, contribute to country's GDP among the others.

In the short run, population has a positive and significant impact on economic growth. That is a unit change in population will result increase in GDP by 11.053. Poverty on the other hand has a negative and insignificant impact on economic growth unlike in the long run case where the relationship is similarly negative but significant. That is $1 \%$ increase in poverty rate will lead to -8.045 decreases in GDP. Unemployment has a positive and significant impact on economic growth which became counterintuitive to a priory expectation. That means $1 \%$ increase in unemployment will decrease GDP by 0.067. At last, Foreign Direct Investment has a negative and insignificant impact on economic growth unlike the long run case where the relationship is negative but significant. Similarly, it's contrary to our expectation. That is $1 \%$ increase in FDI will result decrease in GDP by -0.002. Thus, some of the variables are insignificant in the short run. This shows that those variables take time before they can affect the economy. Further, the case of FDI might be because the amount of Foreign Direct Investment inflow in to the country is too low to affect the economic activities of the country in the shut run. All the variables conform with a priori expectation in the long run, so also in the short run except for unemployment and foreign direct investment where they have been explained above.

The ECT coefficient (-0.757) substantiates the long-run relationship among the variables and denotes that the speed of adjustment of the variables' convergence to equilibrium is $75.7 \%$. The P-value of the F-statistics is less than $5 \%$ (i.e. $0.001<0.05$ ). This means the F-statistics is significant we therefore reject the null hypothesis and conclude that the explanatory variables are jointly significant in influencing the dependent variable GDP. The adjusted $\mathrm{R}^{2}$ is $0.699 \%$. This means that about $69.9 \%$ of the proportion of total variation in economic growth is explained by the explanatory variables, while only $30.1 \%$ of the variation is captured by the error term in the model. The Durbin Watson statistics is 2.320. The DW statistic reveals that there is no problem of first order autocorrelation because it falls between the range of 1.5 and 2.5 .

Table-3. Estimated long-run and short-run coefficients

\begin{tabular}{|c|c|c|}
\hline Dependent Variable GDP & Coefficient & T Ratio (P-Value) \\
\hline \multicolumn{3}{|l|}{ Regressors } \\
\hline \multicolumn{3}{|l|}{ Long Run Results } \\
\hline LPOP & 5.956 & $9.071(0.000)^{* * *}$ \\
\hline LPOV & -6.652 & $-2.504(0.025)^{* *}$ \\
\hline LUNEM & -0.312 & $-3.366(0.004)^{* * * *}$ \\
\hline LFDI & 0.138 & $3.441(0.004)^{* * * *}$ \\
\hline $\mathrm{C}$ & 52.792 & $4.994(0.000)^{* * *}$ \\
\hline \multicolumn{3}{|l|}{ Short Run Results } \\
\hline$\triangle \mathrm{LPOP}$ & 11.053 & $5.143(0.000)$ **** \\
\hline$\triangle \mathrm{LPOV}$ & -8.045 & $-1.524(0.149)$ \\
\hline$\triangle \mathrm{LUNEM}$ & 0.067 & $1.925(0.074)^{*}$ \\
\hline$\Delta \mathrm{LFDI}$ & -0.002 & $-0.179(0.859)$ \\
\hline ECT (-1) & -0.757 & $-5.402(0.000)^{* * *} *$ \\
\hline Adjusted $\mathrm{R}^{2}$ & 0.699 & \\
\hline Durbin Watson statistics & 2.320 & \\
\hline F statistics & $5.147(0.001) * * *$ & \\
\hline
\end{tabular}

\subsection{Diagnostic Tests}

Like any other time-series analysis, diagnostic tests are imperative to assessing the validity, efficiency, and reliability of our model estimate. If the model passes the major diagnostic tests, then the estimate could be reliable. On the contrary, if the models could not surpass the major diagnostic tests, then the deduced inference would be void. The results in Table 4 denote that the Model have passed all the diagnostic tests. Therefore, on the general 
note, our models could produce a reliable outcome having passed all the diagnostic tests of autocorrelation, heteroscedasticity, normality and stability.

Table-4. Diagnostic tests result.

\begin{tabular}{c|c|c}
\hline Type of Test & F-statistics & Probability \\
\hline LM & 0.550 & 0.590 \\
\hline Breusch-Pagan-Godfrey & 0.903 & 0.586 \\
\hline JB & 0.459 & 0.794 \\
\hline RESET & 1.793 & 0.203 \\
\hline
\end{tabular}

As suggested by Pesaran, Shin, and Smith (2001) we have conducted a stability test for the model based on CUSUM and CUSUM of Squares tests. It is suggested that for a model to be stable along the sampled period, the residuals must be within the straight lines of the critical bounds at $5 \%$ significance level. The stability results are depicted in Figure 2. All the figures show that the model is fairly stable over the studied period because the residual lies within the straight line critical bounds at $5 \%$ level of significance.

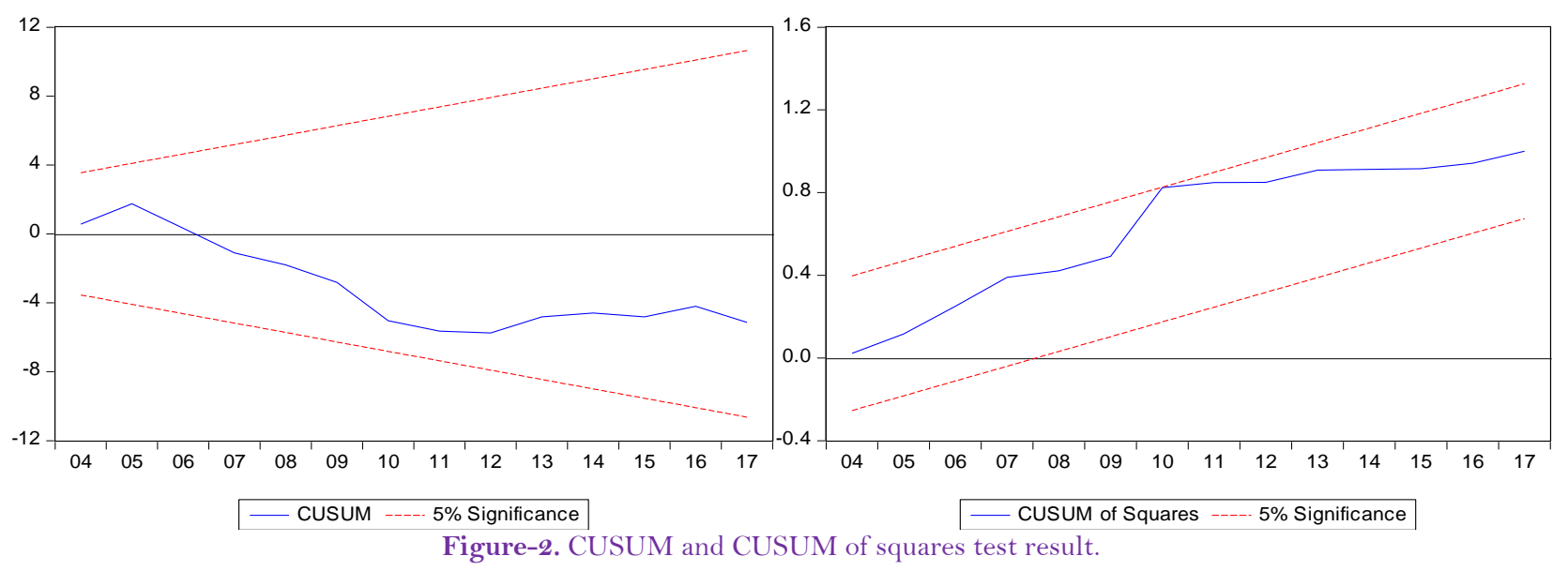

\section{Summary and Conclusion}

This research explores the impact of population growth, poverty and unemployment on economic growth in Nigeria. The empirical review showed a strong link between population and unemployment and poverty on GDP. The study found that some of the variables are stationary at level, that is, $\mathrm{I}(0)$ while others are stationary at first difference, that is, I(1). The ARDL bound Cointegration test were applied and found the existence of long run relationship between variables. The results of the cointegration test showed that there exist cointegrating equation between explanatory variables and GDP. The ECT speed of adjustment to the normal equilibrium confirms their long run relationship of the variables. Finally, the study found that population and FDI have a positive impact while poverty and unemployment has negative impact on GDP. Based on these findings recommend that policy makers should grow the real economic sectors to improve and enhance productivity, exports, job creation, curb inflation and reduce poverty and rapid economic growth and substitute the non-productive imports with domestic products and develop enabling environment to attract foreign private investors. The diagnostic tests were also carried out to check the reliability of the model and the results shows that the model has passed all the diagnostic tests. That is, auto-correction, heteroscedasticity, normality and stability.

\section{References}

Adelowokan, O. A., Maku, O. E., Babasanya, A. O., \& Adesoye, A. B. (2019). Unemployment, poverty and economic growth in Nigeria. Journal of Economics \& Management, 35(1), 1-13.Available at: http://doi.org/10.22367/jem.2019.35.01.

Adewale, E., \& Ademola, J. (2017). Unemployment and inflation: Implication on poverty level in Nigeria. Munich Personal RePEc Archive MPRA, No. (79765), 1-24.

Aiyedogbon, J. O. (2012). Poverty and youth unemployment in Nigeria, 1987-2011. International Journal of Business and Social Science, 3(20), 269-279.

Bala, U., Ayatu, Y., \& Maijamaa, R. (2020). The impact population growth on disaggregate energy generation source from (Hydro Power, Natural Gas, Oil and Coal Source) in Nigeria. Asian Bulletin of Energy Economics and Technology, 5(1), 1-8.Available at: https://doi.org/10.20448/journal.507.2020.51.1.8.

Chisom, G., \& Oluchukwu, F. (2017). Empirical appraisal of poverty-unemployment relationship in Nigeria. International Journal of Economics, $3(6), 91-97$.

Frank, A. C. R. (2010). Unemployment and economic growth in Africa. Oxford Economic Papers, 20(2), $250-274$.

Kurnianto, F. A., Rakhmasari, D., Ikhsan, F. A., Apriyanto, B., \& Nurdin, E. A. (2018). The environment analysis of population growth, unemployment, and poverty level in Maesan District Bondowoso Regency. Geosfera Indonesia, 3(2), 113-121.Available at: https://doi.org/10.19184/geosi.v3i2.8439.

Latimer, A., \& Kulkarni, K. (2008). Population and economic development: A comparative analysis of Brazil and Mexico. Knowledge Hub. The Journal of Rajiv Academy for Technology and Management (RATM), 4(2), 57-70.

Maijamaa, R., Saidu, M. K., Muktari, Y., \& Nafisa, M. (2019). Impact of population growth on unemployment in Nigeria: Dynamic OLS approach. Journal of Economics and Sustainable Development, 10(22), 79-89.

Mamingi, N., \& Perch, J. (2013). Population growth and economic growth/development: An empirical investigation for Barbados. Journal of Economics and Sustainable Development, 4(4), 93-106.

Mansoor, A. (2018). Impact of population, GDP and energy consumption on carbon emissions: Evidence from Pakistan using an analytic tool IPAT. Asian Journal of Economics and Empirical Research, 5(2), 183-190.Available at: https://doi.org/10.20448/journal.501.2018.52.183.190.

Meo, M. S., Khan, V. J., Ibrahim, T. O., Khan, S., Ali, S., \& Noor, K. (2018). Asymmetric impact of inflation and unemployment on poverty in Pakistan: New evidence from asymmetric ARDL cointegration. Asia Pacific Journal of Social Work and Development, 28(4), 295310.Available at: https://doi.org/10.1080/02185385.2018.1523745.

Narayan, P. K. (2005). The saving and investment nexus for China: Evidence from cointegration tests. Applied Economics, 37(17), 19791990.Available at: https://doi.org/10.1080/00036840500278103. 
Njoku, A. C., \& Ihugba, O. A. (2011). Unemployment and Nigerian economic growth (1985-2009). Mediterranean Journal of Social Sciences, 2(6), 23-23.

Nwosa, P. I. (2014). Government expenditure, unemployment and poverty rates in Nigeria. Journal of Research in National Development, 12(1), $77-84$.

Odeh, M. A., \& Okoye, C. (2014). Poverty reduction policy and youth unemployment in Nigeria. Public Policy and Administration Research, $3(4), 92-103$.

Okolobah, V., \& Ismail, Z. (2013). On the issues, challenges and prospects of electrical power sector in Nigeria. International Journal of Economy, Management and Social Sciences, 2(6), 410-418.

OPEC. (2015). OPEC Annual statistical bulletin, Vienna, Au, 108. Retrieved from www.opec.org.

Osinubi, T. S. (2005). Macroeconometric analysis of growth, unemployment and poverty in Nigeria. Pakistan Economic and Social Reviere, $43(2), 249-269$.

Pesaran, M. H., Shin, Y., \& Smith, R. J. (2001). Bounds testing approaches to the analysis of level relationships. Journal of Applied Econometrics, 16(3), 289-326.Available at: https://doi.org/10.1002/jae.616.

Tartiyus, E. H., Dauda, M. I., \& Peter, A. (2015). Impact of population growth on economic growth in Nigeria (1980-2010). Journal of Humanities and Social Science, 20(4), 115-123.

Ukpong, I. G., Ekpebu, I. D., \& Ofem, N. I. (2013). Cointegration inferences on issues of poverty and population growth in Nigeria. Journal of Development and Agricultural Economics, 5(7), 277-283.Available at: https://doi.org/10.5897/jdae12.151.

Citation: Umar Bala; Aminu Ibrahim; Nazeef Bala Hadith (2020). Impact of Population Growth, Poverty and Unemployment on Economic Growth. Asian Business Research Journal, 5: 48-54. History:

Received: 22 September 2020

Revised: 14 October 2020

Revised: 14 October 2020

Accepted: 26 October 2020
Published: 12 November 2020

Licensed: This work is licensed under a Creative Commons

Attribution 3.0 License (cc) E E

Publisher: Eastern Centre of Science and Education
Acknowledgement: All authors contributed equally to the conception and design of the study.

Funding: This study received no specific financial support.

Competing Interests: The authors declare that they have no competing interests.

Transparency: The authors confirm that the manuscript is an honest, Transparency: The authors confirm that the manuscript is an honest,
accurate, and transparent account of the study was reported; that no vital features of the study have been omitted; and that any discrepancies from the study as planned have been explained.

Ethical: This study follows all ethical practices during writing.

Eastern Centre of Science and Education is not responsible or answerable for any loss, damage or liability, etc. caused in relation to/arising out of the use of the content. Any queries should be directed to the corresponding author of the article. 